\title{
Development of a Fuzzy Logic Based Control Algorithm for Maximum Power Point Tracking in a Photovoltaic System
}

\section{Fotovoltaik Bir Sistemde, Maksimum Güç Noktası Takibi için Bulanık Mantık Tabanlı Bir Denetleme Algoritmasının Geliştirilmesi}

\author{
Cem Morkoç ${ }^{1 *}$, Uğur Yüzgeç²
}

Geliş / Received: 21/05/2021

Revize / Revised: 27/09/2021

Kabul / Accepted: 27/10/2021

\begin{abstract}
In this study, a fuzzy logic based maximum power point tracking control algorithm was developed to obtain maximum power continuously from a simulation model of a PV system. Using this simulation model, codes suitable for the TMS320F28335 Digital Signal Processor (DSP) were generated by the embedded code generation method. In this way, the developed algorithm was generated, compiled, sent, and made ready for use in applications with an optimum code structure. The algorithm developed has the task of providing the power demanded by the load unit in a stable and continuous manner; It fulfills this task by providing maximum efficiency from PV panels by Tracking the Maximum Power Point and increasing the power obtained. In addition, the current and voltage of the DC bus as well as the PV panel unit are continuously monitored and used as input data for the algorithm's fuzzy logic controller.
\end{abstract}

Keywords- Fuzzy Logic Controller, Maximum Power Point Tracking, Photovoltaic Systems, Embedded Code Generation

\section{ÖZ}

Bu çalışmada, oluşturulan benzetim modeli kullanılarak, bir PV sisteminden maksimum güç elde etmek için bulanık mantık tabanlı bir maksimum güç noktası takibi denetleme algoritması geliştirilmiştir. Bu benzetim modeli kullanılarak, gömülü kod üretimiy öntemi ile TMS320F28335 Dijital Sinyal İşlemcisi için uygun kodlar oluşturulmuştur. Böylelikle geliştirilen algoritma kodları derlenmiş, işlemciye gönderilmiş ve optimum kod yapısı ile uygulamalarda kullanıma hazır hale getirilmiştir. Geliştirilen algoritma, yük biriminin talep ettiği gücü kararlı ve sürekli bir şekilde sağlama görevini; Maksimum Güç Noktası Takibi yaparak PV panellerinden azami verim sağlanması ile yerine getirmektedir. Ayrıca, DC bara ve PV panel ünitesinin akım ve gerilim verileri sürekli olarak izlenmekte ve algoritmanın bulanık mantık denetleyicisinin girişleri olarak değerlendirilmektedir.

Anahtar Kelimeler- Fotovoltaik Sistemler, Bulanık Mantık Denetleyici, Maksimum Güç Noktası Takibi, Fotovoltaik Sistemler, Gömülü Kod Üretimi

\footnotetext{
1*Sorumlu yazar iletişim: cem.morkoc@bilecik.edu.tr (https://orcid.org/0000-0002-1688-5259)

Enerji Sistemleri Mühendisliği, Bilecik Şeyh Edebali Üniversitesi, Lisansüstü Eğitim Enstitüsü, Bilecik, Türkiye

2̇letișim: ugur.yuzgec@bilecik.edu.tr (https://orcid.org/0000-0002-5364-6265)

Bilgisayar Mühendisliği Bölümü, Bilecik Şeyh Edebali Üniversitesi, Mühendislik Fakültesi, Bilecik, Türkiye
} 


\begin{tabular}{|c|c|c|}
\hline & $\begin{array}{l}\text { BŞEÜ Fen Bilimleri Dergisi } \\
8(2), 949-959,2021\end{array}$ & $\begin{array}{r}\text { BSEU Journal of Science } \\
\text { https://doi.org/10.35193/bseufbd.940581 }\end{array}$ \\
\hline 0 & & 2458-7575 (https://dergipark.org.tr/tr/pub/bseufbd) \\
\hline
\end{tabular}

\section{INTRODUCTION}

In these days at the beginning of the 21st century, energy demand is increasing day by day. However, in order to meet this energy need, it is thought that choosing renewable energy sources (RES) instead of fossil-based fuels, which have very harmful effects on the environment such as greenhouse gas emissions and pollution, will minimize these effects. The use of RES is no longer a matter of preference for societies that think of the future and becomes a necessity. According to OECD data, the contribution rate of RESs to the total primary energy supply (TPES) is increasing both in our country and all over the world [1].

Solar energy is one of the most important and sustainable RES. Photovoltaic (PV) panels are widely used in recent years to take advantage of the infinite energy of the Sun. This energy, which reaches the Earth from the Sun by traveling a long way, varies depending on atmospheric events [2].There are many applications in the literature where the energy obtained from PV panels is used directly [3-6].However, this way of use reduces efficiency considerably. In addition, in applications where PV panels are not used efficiently, it may be necessary to use more panels to generate the demanded energy. This means both an increase in costs and the carbon footprint against the intended use of RES.

For such reasons, it is very important to continuously monitor the energy obtained from PV panels and to try to obtain maximum efficiency. In line with this purpose, applications that perform maximum power point tracking (MPPT) increase efficiency by providing maximum power from PV panels continuously [7,8]. When these applications are examined, it is seen that PI or PID controllers are used for reasons, such as being easier to understand and applicable [9-11]. However, when the relevant literature is examined, it is seen that the parameters of these controllers, which have a simple structure, are determined by trial and error. This method used in parameter determination also prolongs and complicates the system design process. In addition, the system parameters need to be rearranged in case of any change that may occur in the system to be controlled (changing the system scale, adding a different energy element, etc.). On the other hand, when it comes to complex structured nonlinear systems, these controllers are insufficient.

In PV panel applications, system parameters are constantly changing due to its nature. Using adaptive controllers like Fuzzy Logic Controller that can quickly respond to variable system parameters may be appropriate to overcome such constraints. Considering all these cases, fuzzy logic controllers are preferred in applications where MPPT is desired, despite the need to develop more complex algorithms and apply more effective coding techniques due to their relatively more complex mathematical calculations [12-17].

\section{SYSTEM STRUCTURE}

\section{A. PV System}

As can be seen in Figure 1, the system consists of the PV panel unit used as energy source, the load unit, the DC-DC boost converter unit that is responsible for increasing and transferring the power to be obtained from the PV panels to the load, and the fuzzy logic-based MPPT algorithm unit that generates the switching signals required for this converter. 


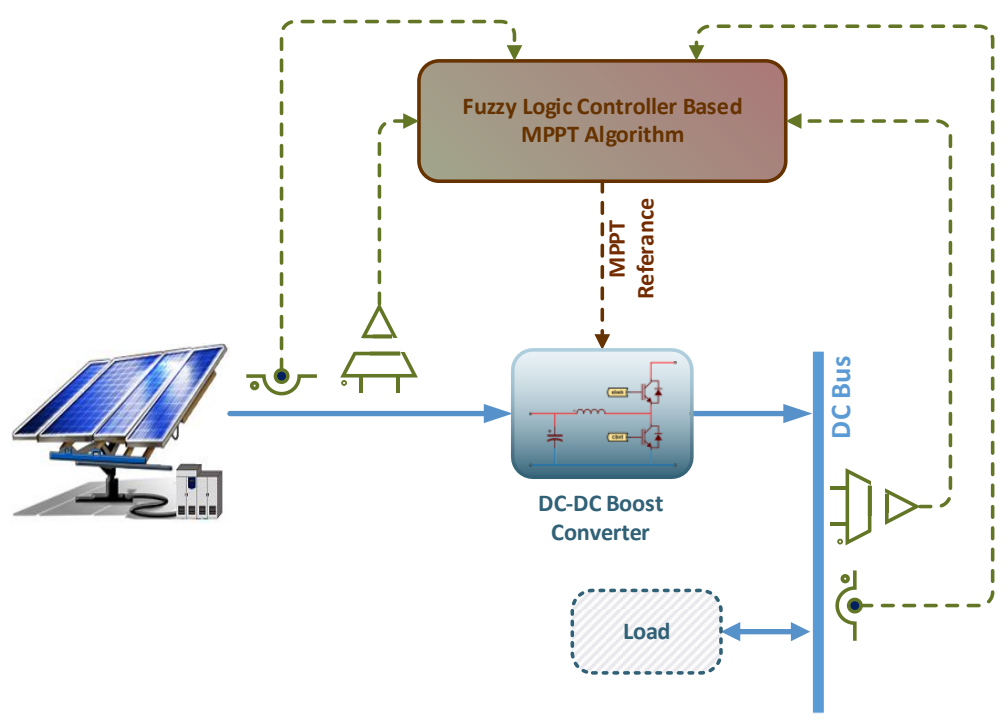

Figure 1. PV system general schematic

\section{B. Simulation Model}

The PV panel unit, which is the energy source of the system, has been simulated on the PSIM program by using the catalog values given in Table 1 . In the same direction, a simulation model was created in the PSIM program for a typical DC-DC boost converter shown in Figure 2. The developed algorithm is written in the Simplified C block in the PSIM program using the C programming language. The load unit is modeled with a resistor. The system simulation model created is shown in Figure 3. In this simulation model, the PV panel unit, load unit and DSP environment are represented by green, orange and yellow regions, respectively. All elements are considered as ideal in the simulation system.

Table 1. Perlight PLM-100 PV panel catalog data

\begin{tabular}{ll}
\hline Maximum Power (Pmax) & $100 \mathrm{~W}$ \\
Maximum Current (Imax) & $5.85 \mathrm{~A}$ \\
Maximum Voltage (Vmax) & $17.1 \mathrm{~V}$ \\
Short Circuit Current (Isc) & $1.36 \mathrm{~A}$ \\
\hline
\end{tabular}

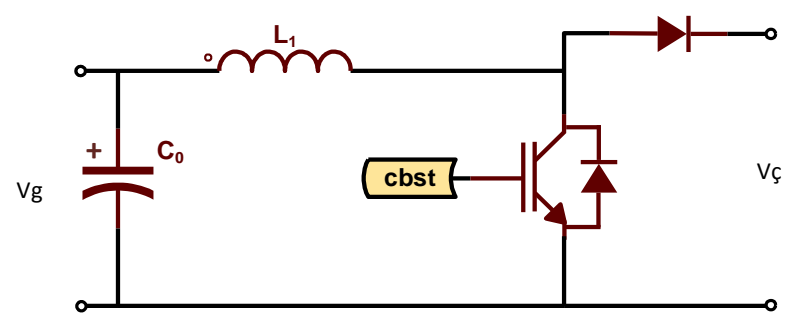

Figure 2. DC-DC boost converter [18] 


\begin{tabular}{|c|c|c|}
\hline & $\begin{array}{l}\text { BŞEÜ Fen Bilimleri Dergisi } \\
8(2), 949-959,2021\end{array}$ & $\begin{array}{r}\text { BSEU Journal of Science } \\
\text { https://doi.org/10.35193/bseufbd.940581 }\end{array}$ \\
\hline & & 2458-7575 (https://dergipark.org.tr/tr/pub/bseufbd) \\
\hline
\end{tabular}

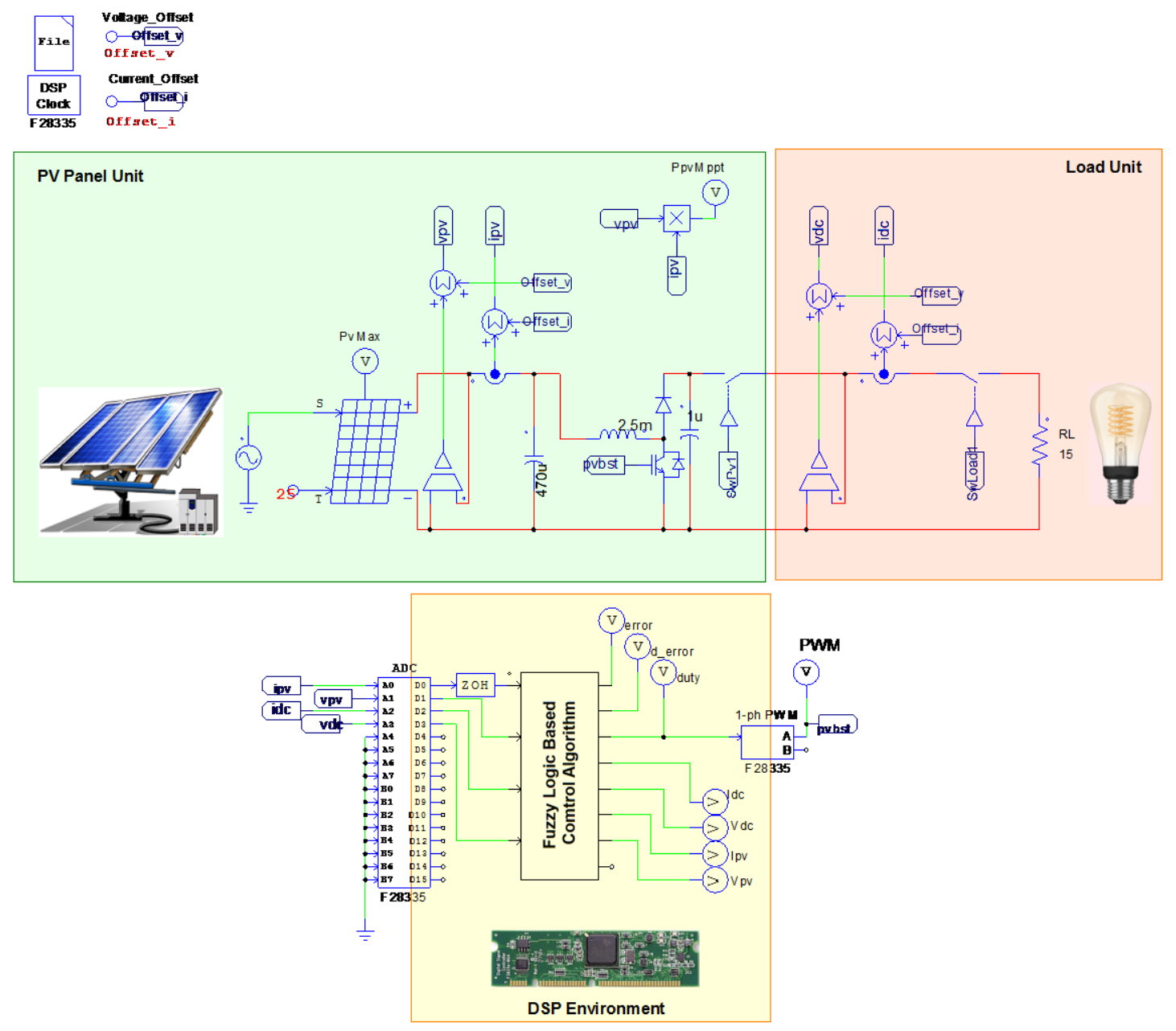

Figure 3. Simulation model of the proposed system

The PV panel model block has two inputs that represent temperature and irradiance values. The temperature input is set to be $25^{\circ} \mathrm{C}$, which is the ideal temperature at which catalog data were obtained. Irradiation input values are entered according to the amount of radiation that differs during the day. Thus, it is possible to monitor the response of the system to varying irradiance values. This block also outputs the maximum power that can be obtained from the PV panel. This enables the results obtained from the developed fuzzy logic-based MPPT algorithm to be compared with the values they should have, thus evaluating the performance of the developed algorithm.

A resistor is used to represent the loads to be connected to the system. In addition, the current and voltage values at the output of the PV panel and on the load, which are very important for the developed algorithm, were determined using the relevant sensors. The DSP environment has also been simulated so that the microcontroller embedded codes can be automatically generated. In order to process the measured analog values by DSP, an analog to digital converter (ADC) block, to generate DC-DC boost converter switching signals according to the determined duty ratio value a pulse width modulation (PWM) block, and to write the developed algorithm in $\mathrm{C}$ language a Simplified C block were used.

\section{Fuzzy Logic Controller Based MPPT Algorithm}

The flow chart of the developed fuzzy logic controller-based MPPT algorithm is shown in Figure 4. Here, first of all, the voltage and current values on the PV panel and the load are measured with sensors and converted into digital data with the ADC block. One or more of the maximum powers, voltage or current values given in the catalog values of the PV panels (voltage reference is preferred in this application) are determined as reference values. PV panel power and power on the load are calculated. The error and the change of error, which are the 
input values of the designed two input and one output fuzzy logic controller, are determined. Here, the error is determined as the difference between the PV panel voltage and the reference voltage, which is also the PV panel catalog value, the maximum PV panel voltage at maximum power. The change of error was determined as the difference between the current error value and the previous error value. Subsequently, these entries were fuzzified using the Mamdani method by using membership functions in the fuzzify step [19]. Seven triangular type membership functions determined for each entry were created as given in Figure 5, and these functions were defined in a matrix in $\mathrm{C}$ language. Membership function was selected between -1 and 1 for error entry, while a smaller range of -0.1 to 0.1 was selected for change of error. In the rule base step, it is calculated which rule in the rule base corresponds to the fuzzy values obtained in the previous step. The rule base used is shown in Figure 6 . Thus, active rules and the activity levels of these rules were determined.

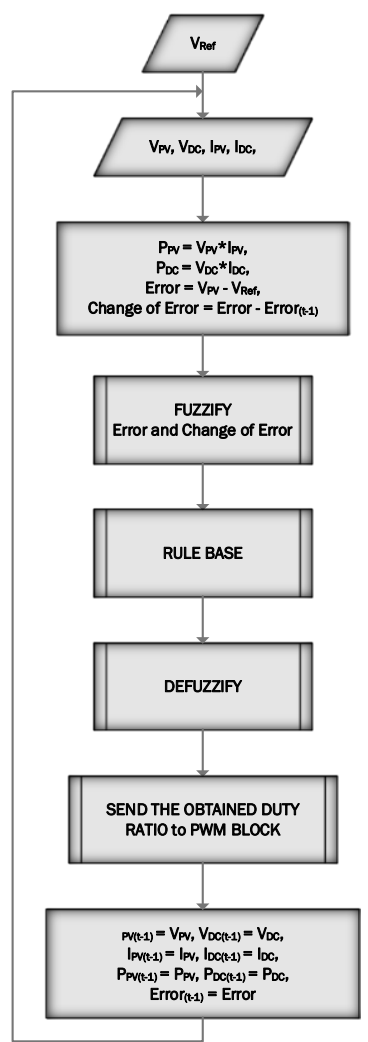

Figure 4. Flowchart of the proposed fuzzy logic controller based MPPT algorithm
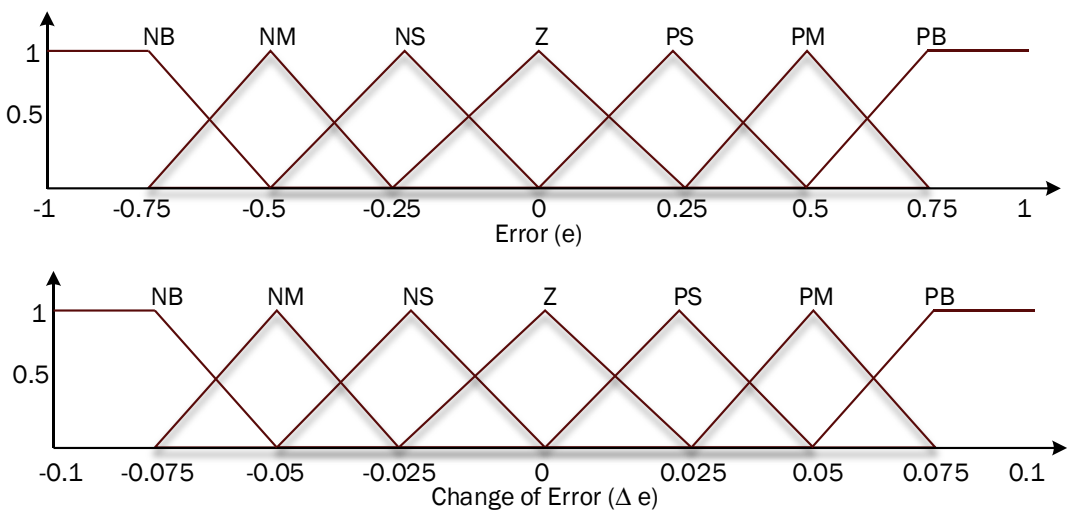

Figure 5. Triangular membership functions determined for error and change of error 


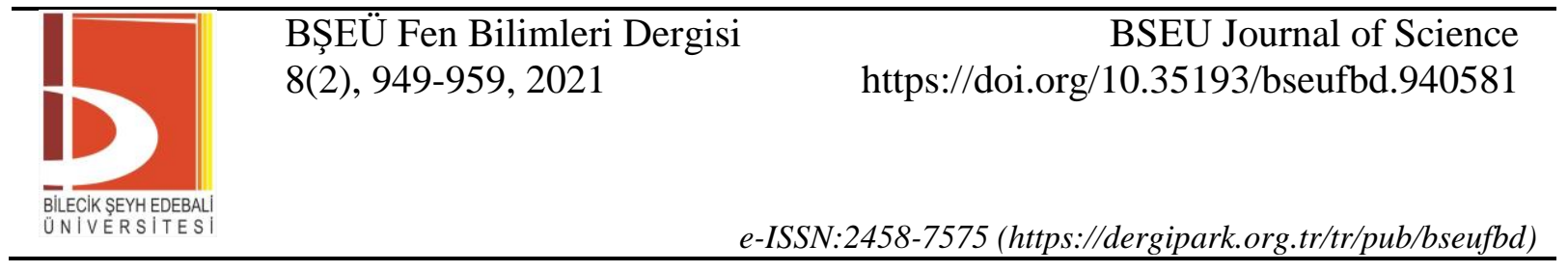

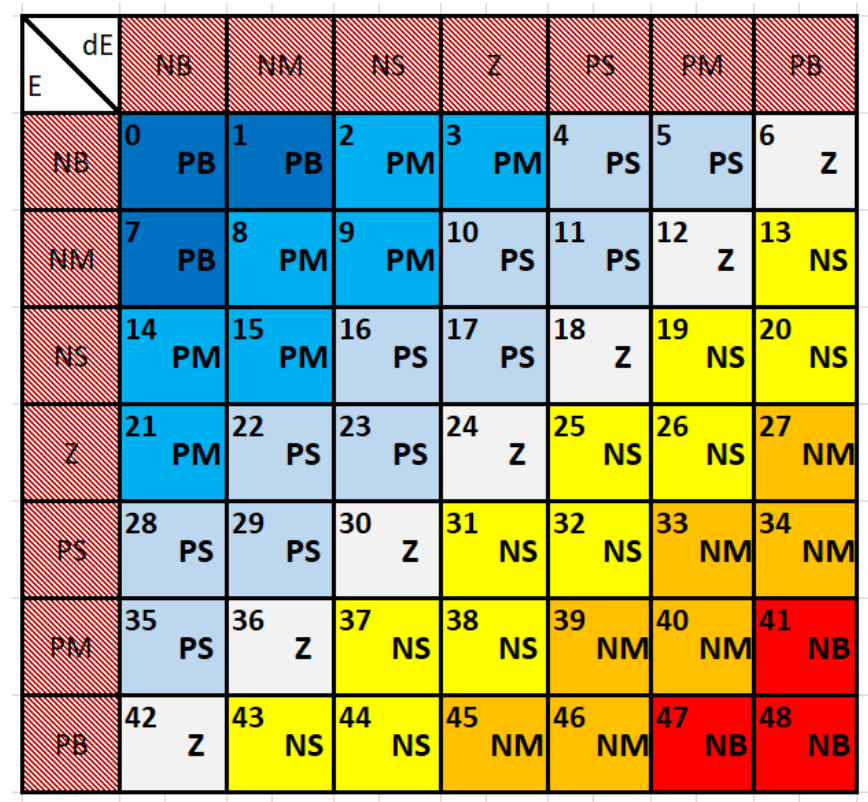

Figure 6. Rule base table

In the defuzzification step, the defuzzification process was carried out by means of Equation 1 by using the center of gravity method. As can be seen in Figure 7, seven triangular membership functions for output have been selected so that their value range is 0.1 to 0.7 . Since the duty ratio to be obtained at the output of this step takes a value below 0.1 or above 0.7 , it will affect the switching process negatively, so a range has been determined so that these values will not be exceeded. The defuzzified value obtained is sent to the PWM block of the microcontroller to generate the switching signals of the DC - DC boost converter. The error and the change of error values, as well as the current, voltage and power values of the PV panel and the load, saved as previous values for the next cycle. Then the algorithm returns to the beginning. Thus, the algorithm recalculates the duty ratio according to the new voltage, current, and power values.

$$
\text { Defuzzified Output }=\frac{\sum \mu_{o}(i) \cdot i}{\sum \mu_{o}(i)}
$$

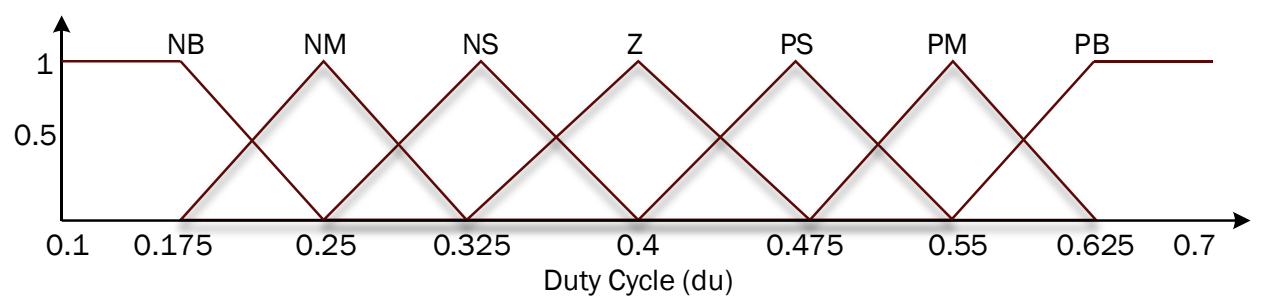

Figure 7. Triangular membership functions determined for output duty cycle

\section{SIMULATION RESULTS}

The amount of irradiation and consequently the maximum power that can be obtained from PV panels varies during the day. While catalog data is determined by the manufacturer, the amount of irradiation is kept constant (best condition) as $1000 \mathrm{~W} / \mathrm{m}^{2}$. However, in the real world, the change in the irradiance is a parabola-like curve whose values are zero at the time of sun rise and sun set, and maximum at the solar noon when the angle between the panel axis and the sunlight rays is zero. In line with this information, in the simulation study, the change of irradiation was determined to represent the change during the day by increasing from $0 \mathrm{~W} / \mathrm{m}^{2}$ to 1000 $\mathrm{W} / \mathrm{m}^{2}$ and decreasing to $0 \mathrm{~W} / \mathrm{m}^{2}$ again and this cycle was repeated twice within a $200 \mathrm{~ms}$ simulation period. While the maximum power that can be obtained from PV panels according to these irradiance values is shown with the red curve in Figure 8, the power obtained from the PV panels by making MPPT with the developed algorithm is shown with the blue curve and the change in the irradiation is shown in green curve. 


\begin{tabular}{|c|c|c|}
\hline & $\begin{array}{l}\text { BŞEÜ Fen Bilimleri Dergisi } \\
8(2), 949-959,2021\end{array}$ & $\begin{array}{r}\text { BSEU Journal of Science } \\
\text { https://doi.org/10.35193/bseufbd.940581 }\end{array}$ \\
\hline & & :2458-7575 (https://dergipark.org.tr/tr/pub/bseufbd) \\
\hline
\end{tabular}

Accordingly, it has been observed that the power obtained from PV panels captures the maximum power that can be obtained from PV panels at the end of approximately $3 \mathrm{~ms}$ and follows it continuously during the simulation period of $200 \mathrm{~ms}$. In other words, it was concluded that the developed algorithm ensures that the maximum power is obtained from the PV panels continuously.

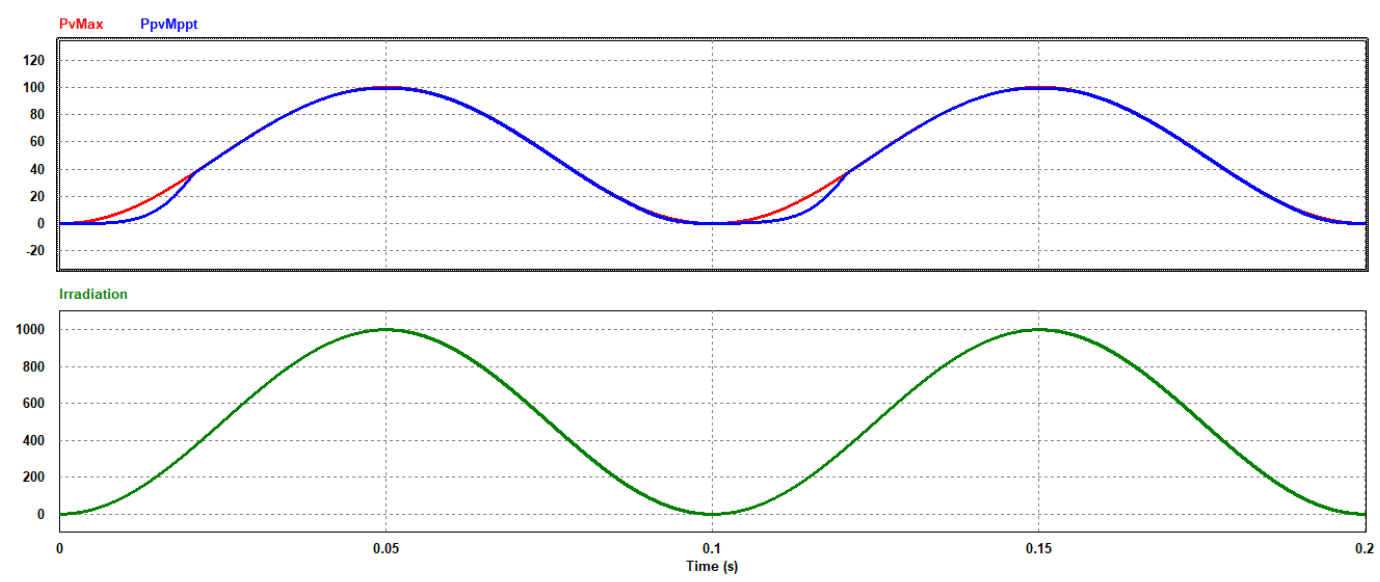

Figure 8. Maximum power curves that can be obtained from PV panels in response to varying (parabola-like) amount of irradiation

In addition, although the change in irradiance will not be so sharp during the day, in order to better demonstrate the performance of the proposed algorithm, step by step increased and decreased irradiation change values were also applied, as preferred in many studies in the literature. In this direction, the irradiance increased step by step from $0 \mathrm{~W} / \mathrm{m}^{2}$ to $400 \mathrm{~W} / \mathrm{m}^{2}$ and to $1000 \mathrm{~W} / \mathrm{m}^{2}$ and then decreased to $600 \mathrm{~W} / \mathrm{m}^{2}$ and $0 \mathrm{~W} / \mathrm{m}^{2}$ within a $250 \mathrm{~ms}$ simulation period. While the maximum power that can be obtained from PV panels according to these irradiance values is shown with the red curve in Figure 9, the power obtained from the PV panels by making MPPT with the developed algorithm is shown with the blue curve and the change in the irradiation is shown in green curve. Thus, the response of the system to different amounts of irradiation during the day, represented in a very aggressive manner, could be monitored.

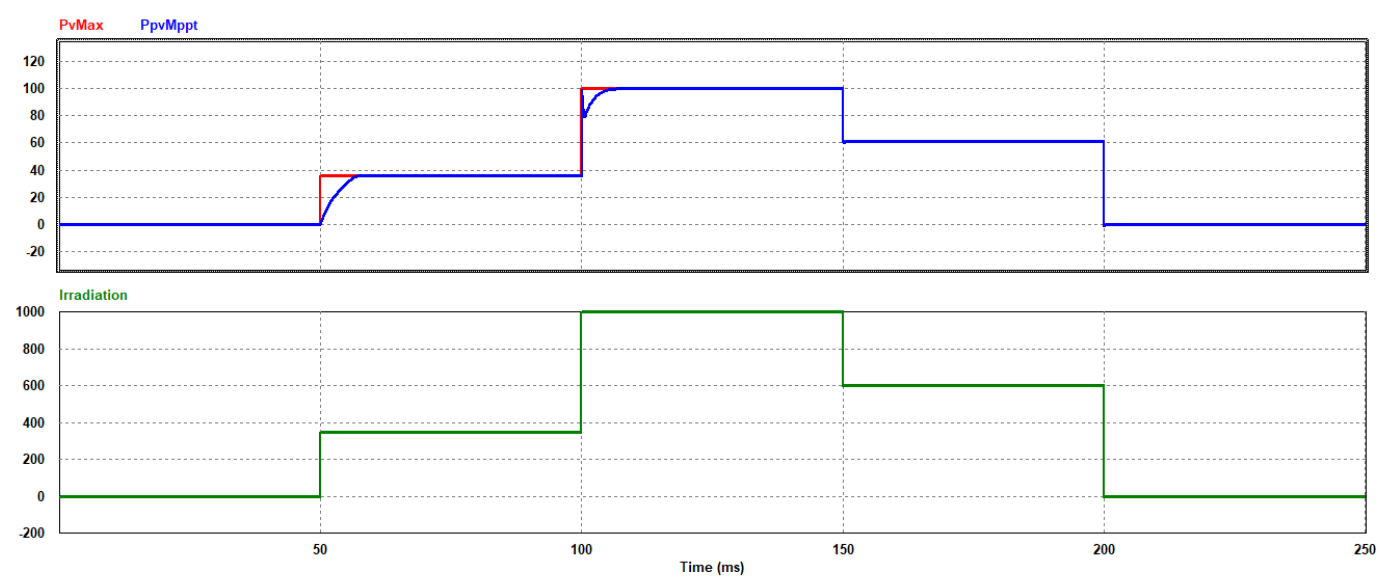

Figure 9. Maximum power curves that can be obtained from PV panels in response to varying (step up - down) amount of irradiation

Accordingly, it has been observed that the power obtained from PV panels captures the maximum power that can be obtained from PV panels at the end of approximately $3 \mathrm{~ms}$ and follows it continuously during the simulation period of $200 \mathrm{~ms}$. In other words, it was concluded that the developed algorithm ensures that the maximum power is obtained from the PV panels continuously.

Figure 10 and 11 shows the current (red) and voltage (blue) curves of the PV panels during simulation for parabola-like and step up - down varying irradiation respectively. Accordingly, it is seen that the PV panel 


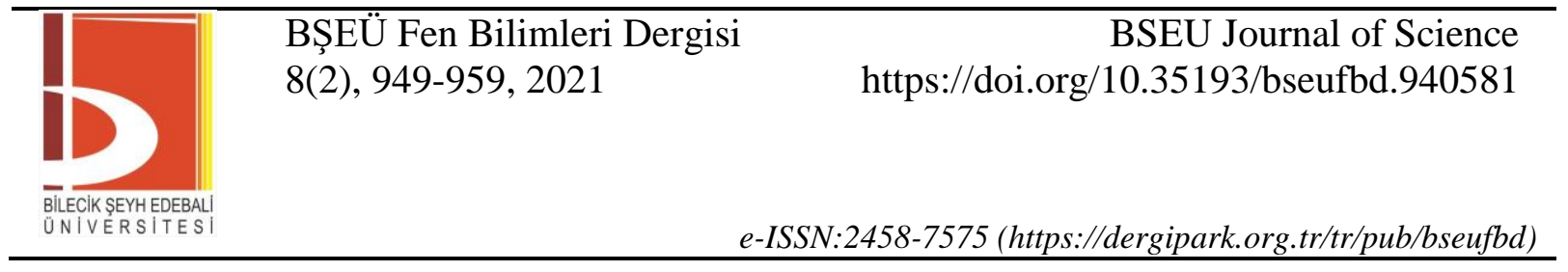

voltage approaches the specified reference voltage and catches it after $3 \mathrm{~ms}$, whereas the PV panel current changes in order to obtain maximum power.
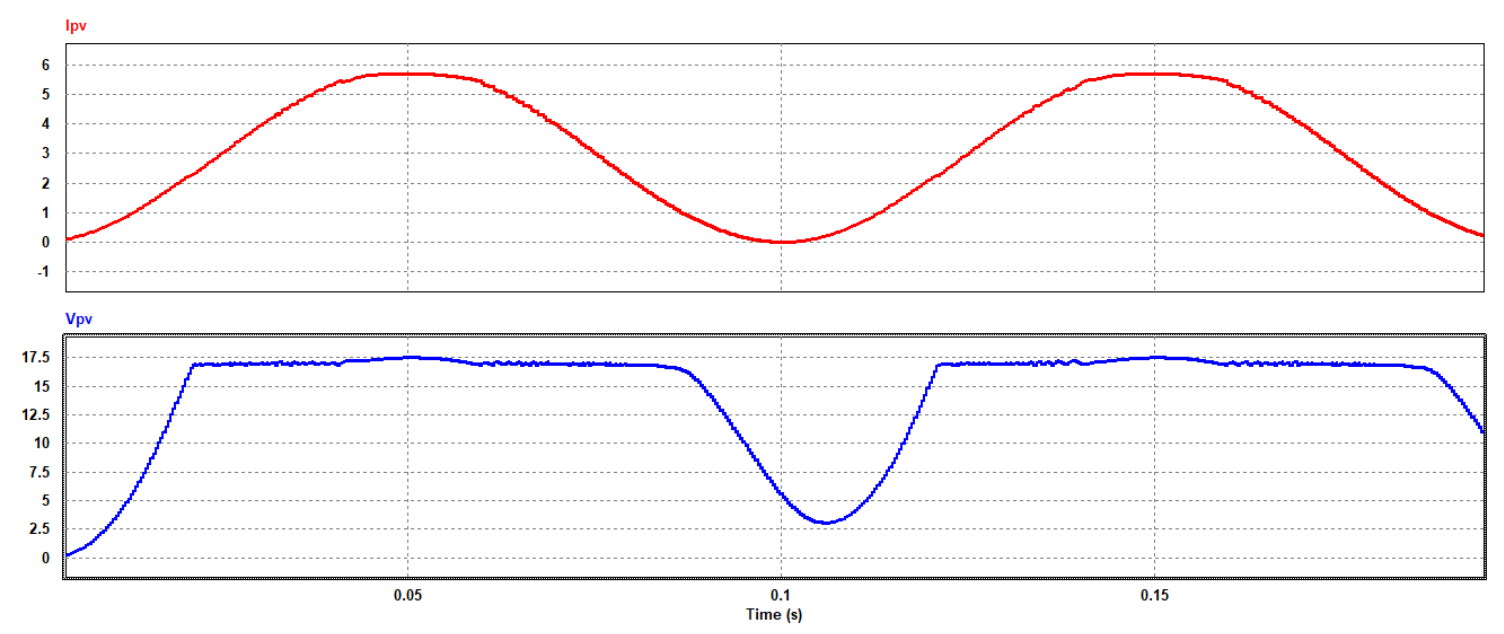

Figure 10.Current (red) and voltage (blue) curves of the PV panels (parabola-like varying irradiation)
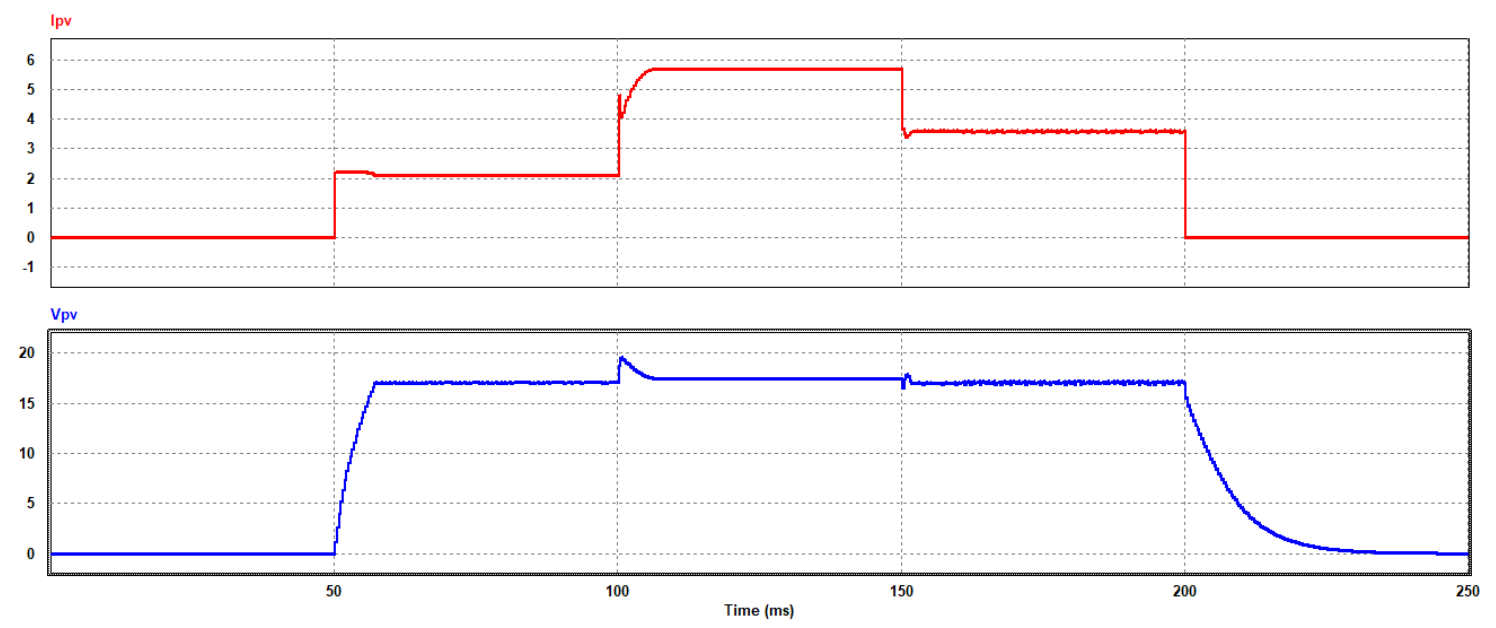

Figure 11. Current (red) and voltage (blue) curves of the PV panels (step up - down varying irradiation)

In Figure 12 and 13, the duty ratio curve obtained as a result of the developed algorithm is shown in red, whereas the active rules of the fuzzy logic controller are shown with blue curve for parabola-like and step up down varying irradiation respectively. Accordingly, it is seen that the required duty ratio values are obtained within the specified limits $(0.1-0.7)$ in the developed algorithm, and the active rule in the rule base changes as it should. It is also seen that the active rule and duty ratio change more aggressively, especially for irradiation values between $600 \mathrm{~W} / \mathrm{m}^{2}$ and $900 \mathrm{~W} / \mathrm{m}^{2}$. 


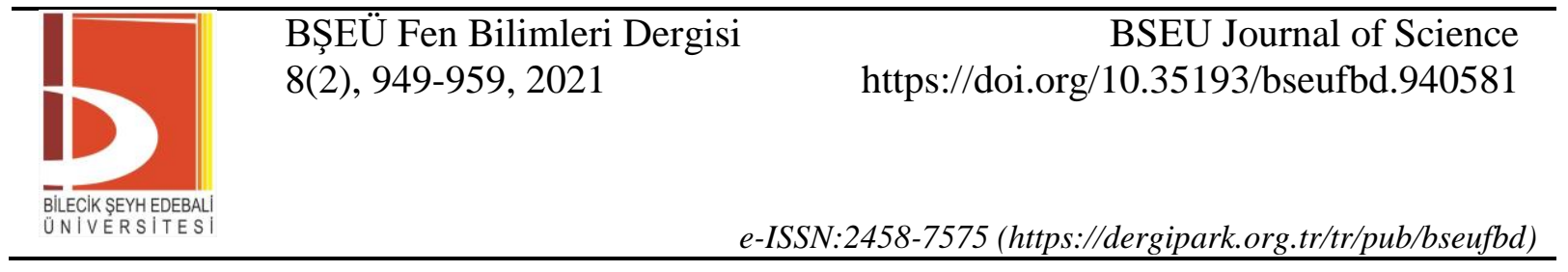
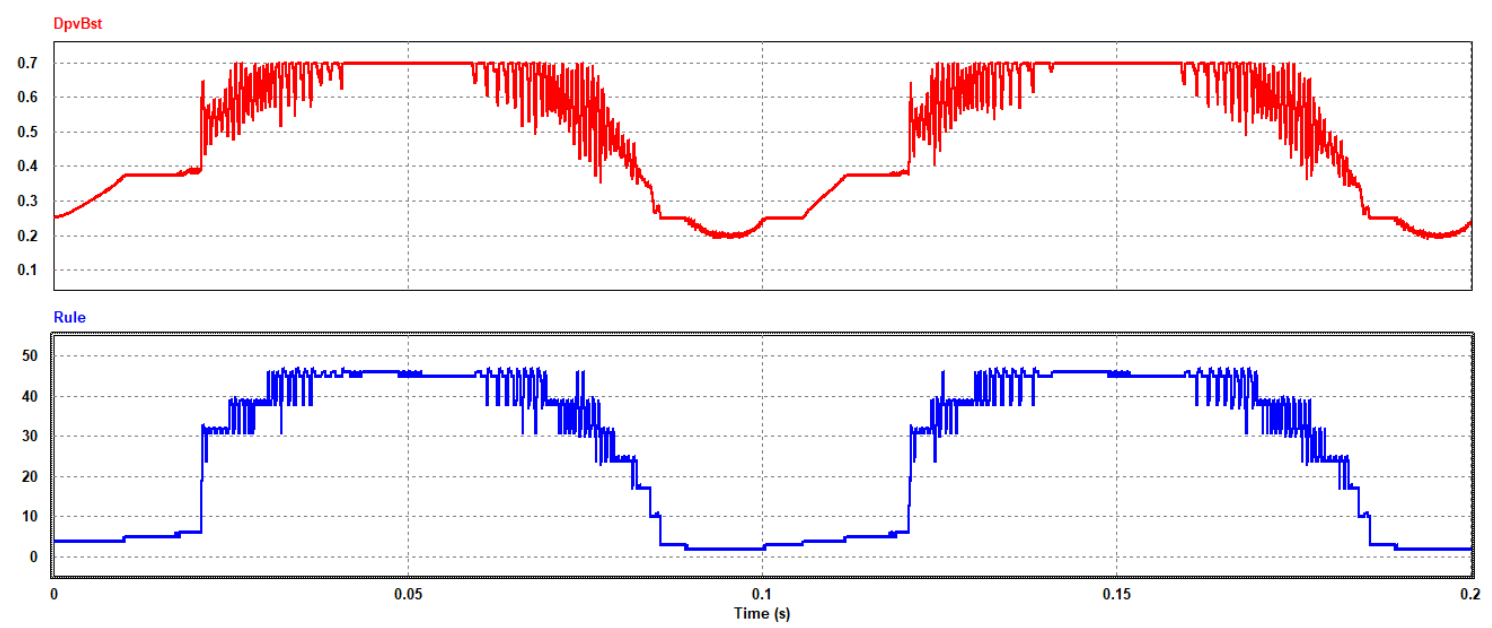

Figure 12. Duty ratio (red) and active rule (blue) curves (parabola-like varying irradiation)
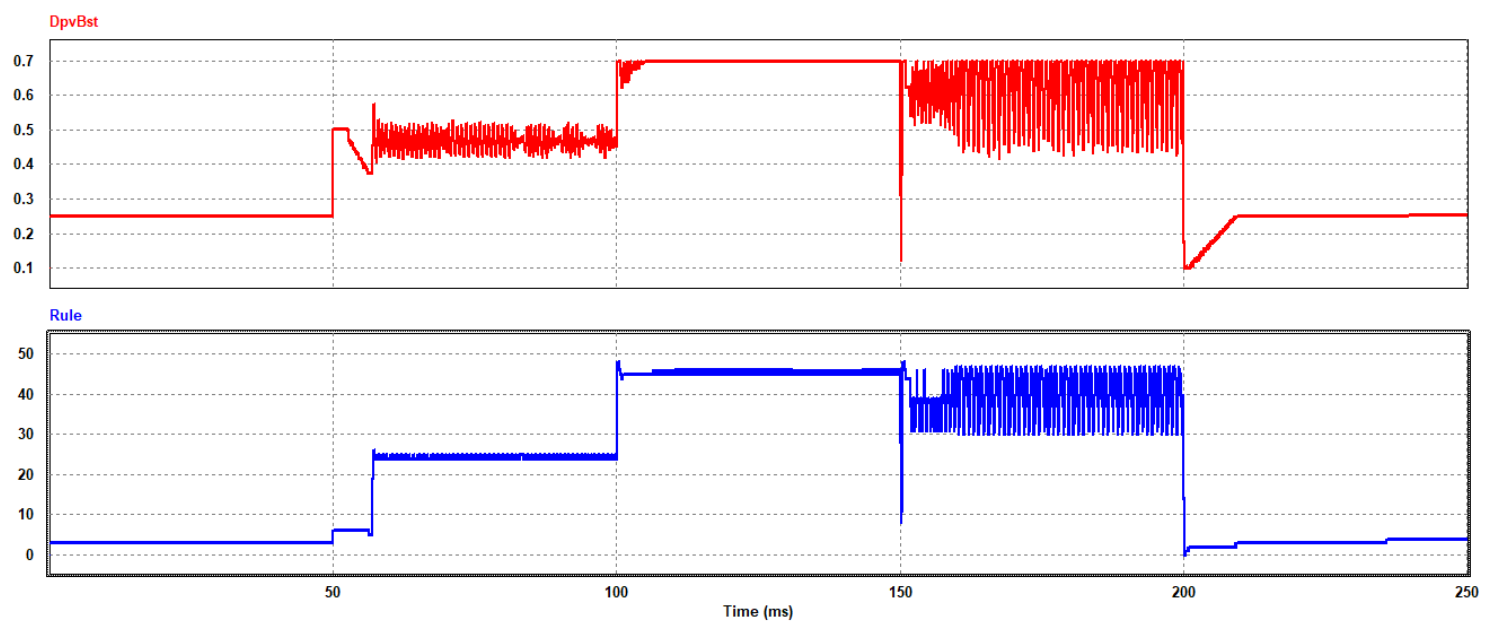

Figure 13. Duty ratio (red) and active rule (blue) curves (step up - down varying irradiation)

In Figure 14, comparison of simulation system results without MPPT (1), with MPPT (2) and irradiance curves are shown.
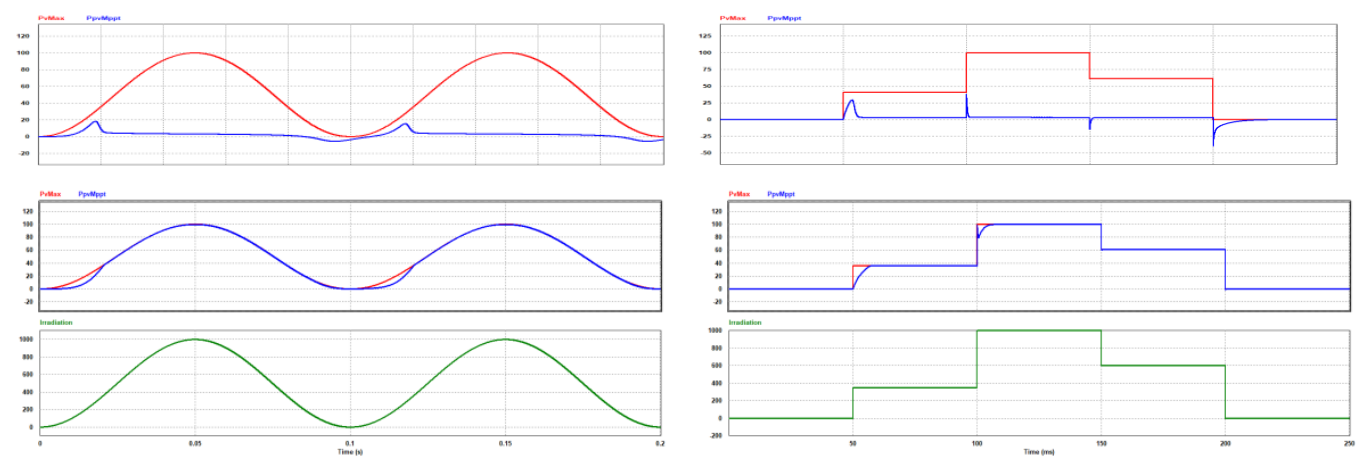

(a)

(b)

Figure 14. Power response without and with MPPT algorithm and irradiance curves (a) parabola-like varying irradiation (b )step up - down varying irradiation 


\begin{tabular}{|c|c|c|}
\hline & $\begin{array}{l}\text { BŞEÜ Fen Bilimleri Dergisi } \\
8(2), 949-959,2021\end{array}$ & $\begin{array}{r}\text { BSEU Journal of Science } \\
\text { https://doi.org/10.35193/bseufbd.940581 }\end{array}$ \\
\hline & & :2458-7575 (https://dergipark.org.tr/tr/pub/bseufbd) \\
\hline
\end{tabular}

\section{CONCLUSIONS}

The performance of the proposed fuzzy logic controller-based MPPT algorithm is determined by calculating its MPPT efficiency using equation 2. This calculation is obtained by the ratio of the power obtained from the PV panels to the maximum power that can be obtained from the PV panels(instant values obtained from the PSIM photovoltaic panel model block), which are given (the first 10 out of 16834 instances) in Table 2 and 3. Accordingly, the MPPT efficiency of the proposed algorithm was calculated as $95.4 \%$ when the first moment values are taken into consideration with the effect of other elements in the simulation model (Table 2), and 96.8\% when the first moment values are ignored (Table 3).Power losses such as switching mosfets of the DC-DC converter are ignored in the simulation environment.

$$
\text { MPPT Efficiency of Proposed Algorithm }=\frac{\sum \text { power obtained from the PV instances }}{\sum \text { maximum power that can be obtained from the PV instances }}
$$

Table 2.The power obtained from the PV panels and the maximum power that can be obtained from the PV panels (instant values obtained from the PSIM photovoltaic panel model)

With the first moment values are taken into consideration, 16834 instances for each one

\begin{tabular}{cc}
\hline The power obtained from the PV panels & $\begin{array}{c}\text { The maximum power that can be obtained from the PV panels (instant } \\
\text { values obtained from the PSIM photovoltaic panel model) }\end{array}$ \\
0 & 63.909063140872121 \\
0 & 63.909063140872121 \\
0 & 63.909063140872121 \\
0 & 63.909063140872121 \\
0 & 63.909063140872121 \\
0 & 63.909063140872121 \\
0 & 63.909063140872121 \\
0 & 63.909063140872121 \\
0 & 63.909063140872121 \\
$\ldots$ & 63.909063140872121 \\
$\ldots$ & $\ldots$ \\
\hline
\end{tabular}

Table 3. The power obtained from the PV panels and the maximum power that can be obtained from the PV panels (instant values obtained from the PSIM photovoltaic panel model)

Without the first moment values are taken into consideration, 15534 instances for each one (first 1300 instances are not used)

\begin{tabular}{cc}
\hline The power obtained from the PV panels & $\begin{array}{c}\text { The maximum power that can be obtained from the PV panels (instant } \\
\text { values obtained from the PSIM photovoltaic panel model) }\end{array}$ \\
64.622346722114855 & 69.123681323069476 \\
64.622346722114855 & 69.123681323069476 \\
65.498284042390893 & 69.123681323069476 \\
65.498284042390893 & 69.123681323069476 \\
65.498284042390893 & 69.123681323069476 \\
65.498284042390893 & 69.19166801434605 \\
65.498284042390893 & 69.19166801434605 \\
65.498284042390893 & 69.19166801434605 \\
65.498284042390893 & 69.19166801434605 \\
65.498284042390893 & 69.19166801434605 \\
$\ldots$ & $\ldots$ \\
\hline
\end{tabular}

As a result, the usability of a fuzzy logic-based control algorithm instead of classical control algorithms, which are inadequate due to changes in the amount of radiation and nonlinear system parameters in PV panel applications, has been confirmed.

\section{REFERENCES}

[1] OECD. (2021), Renewable energy (indicator). doi: 10.1787/aac7c3f1-en (Accessed on 15 March 2021)

[2] Karafil, A., Ozbay, H, \& Kesler, M. (2016). Temperature and solar radiation effects on photovoltaic panel power. Journal of New Results in Science, 5, 48-58.

[3] Ryu, S. H., Kim, D. H., Kim, M. J., Kim, J. S., \& Lee, B. K. (2014). Adjustable Frequency-Duty-Cycle Hybrid Control Strategy for Full-Bridge Series Resonant Converters in Electric Vehicle Chargers. Industrial Electronics, 61(10), 5354-5362. 
[4] Chuang, Y. C., Ke, Y. L., Chuang, H. S., \& Chen, H. K. (2009). Implementation and analysis of an improved seriesloaded resonant DC-DC converter operating above resonance for battery chargers. Industry Applications, IEEE Transactions on, 45, (3), 1052-1059.

[5] Chui, H. J., Lo, Y. K., Lee, T. P., Chen, Q. S., Yu, W. L., Lee, J. X., \& Mou, S. C. (2011). A battery charger with maximum power point tracking function for lowpower photovoltaic system applications. International Journal of Circuit Theory and Applications, 39(3), 241-256.

[6] Hseih, H. I., Shih, S. F., Hseih, J. H., \& Hsieh, G. C. (2012). A study of high-frequency photovoltaic pulse charger for lead-acid battery guided by PI-INC MPPT. Renewable Energy Research and Applications (ICRERA), International Conference on. IEEE, 1-6.

[7] Ozbay H. (2020). Rezonans Dönüştürücülü Fotovoltaik Batarya Şarj Sistemi. Journal of Engineering Sciences and Researches, 2(1), 11-20.

[8] Esram, T., \& Chapman, P. L. (2007). Comparison of photovoltaic array maximum power point tracking techniques. IEEE Transactions on Energy Conversion EC, 22(2), 439.

[9] Zou, X., Tang, A., Liu R., \& Wang, Y. (2021). Research on MPPT Algorithm Based on Variable Step Size Conductance Increment + PI Method. IEEE 5th Advanced Information Technology. Electronic and Automation Control Conference (IAEAC). 829-833.

[10] Kabalci, E., Gokkus, G. \& Gorgun, A. (2015). Design and implementation of a PI-MPPT based Buck-Boost converter. 7th International Conference on Electronics, Computers and Artificial Intelligence (ECAI). 23-28.

[11] Khaled, A., Aboubakeur, H., Mohamed B., \& Nabil, A. (2018). A Fast MPPT Control Technique Using PID Controller in a Photovoltaic System. 2018 International Conference on Applied Smart Systems (ICASS), Medea, Algeria. 1-5.

[12] Bhattacharyya, S., Kumar, P. D. S., Samanta, S., \& Mishra, S. (2021). Steady Output and Fast Tracking MPPT (SOFT-MPPT) for P\&O and InC Algorithms, in IEEE Transactions on Sustainable Energy, 12(1). $293-302$.

[13] Sher, H. A., Murtaza, A. F., Noman, A., Addoweesh, K. E., Al-Haddad, K., \& Chiaberge, M. (2015). A New Sensorless Hybrid MPPT Algorithm Based on Fractional Short-Circuit Current Measurement and P\&O MPPT. in IEEE Transactions on Sustainable Energy, 6(4), 1426-1434.

[14] Ali A., et al., (2020). Investigation of MPPT Techniques Under Uniform and Non-Uniform Solar Irradiation Condition-A Retrospection. in IEEE Access, 8. 127368-127392.

[15] Al Nabulsi, A., \& Dhaouadi, R. (2012). Efficiency Optimization of a DSP-Based Standalone PV System Using Fuzzy Logic and Dual-MPPT Control. in IEEE Transactions on Industrial Informatics, 8(3), 573-584.

[16] Abbes, H., Loukil, K., Abid, H., Abid, M., \& Toumi, A. (2015). Implementation of a Maximum Power Point Tracking fuzzy controller on FPGA circuit for a photovoltaic system. 15th International Conference on Intelligent Systems Design and Applications (ISDA). 386-391.

[17] Rezk, H., Aly, M., Al-Dhaifallah, M., \& Shoyama, M. (2019). Design and Hardware Implementation of New Adaptive Fuzzy Logic-Based MPPT Control Method for Photovoltaic Applications. in IEEE Access, 7, 106427-106438.

[18] Rashid, M. (1993). Power Electronics Circuits, Devices And Applications. Prentice Hall (Second Edition),

[19] Ying, H. (2000). Mamdani Fuzzy PID Controllers. in Fuzzy Control and Modeling: Analytical Foundations and Applications, IEEE. 41-8. 